\title{
ORAL PERFORMANCE OF İRĖGÚN MUSIC IN YAGBALAND, KOGI STATE, NIGERIA: AN OVERVIEW
}

\author{
Stephen Olusegun Titus, \\ Obafemi Awolowo University, Nigeria.
}

\begin{abstract}
Performance is one of the major arts in most African countries. Among the Yoruba in Nigeria several genre of oral performance has been researched and documented. These include the ijala, iwi, oriki ekun iyawo, Iyere Ifa, iwure, among others. However, very little attention and studies have been committed to oral performance of İrègún chants and songs in Yagbaland. This paper, therefore, focuses on the evaluation of oral performance of İrègún chants and songs among Yagba people in Kogi State, located in North central of Nigeria. Primary data were collected through 3 In-depth and 3 Key Informant interviews of leaders and members of İrègún musical groups. In addition to 3 Participant Observation and 3 Non-Participant Observation methods from Yagba-West, Yagba-East and Mopamuro Local Government Areas of Kogi State, music recordings, photographs of İrègún performances, and 6 chants were purposefully sampled. Secondary data were collected through library, archival and Internet sources. Although closely interwoven, İrègún performance is structured into preparation, actual and post-performance activities. While chanting, singing, playing of musical instruments and dancing forms the performance dimensions. Iregun music serves as veritable mirror and cultural preserver in Yagba communities.
\end{abstract}

Keywords: Iregun Music; Performance; Yagbaland; Chants and Songs 


\section{Introduction}

Performance of oral genre varies in Yoruba culture as varied as contexts for performance. In essence, oral performance can only be realized when it is actually performed. Oral performance necessarily developed its own methodology and its artistic approach basically in the mouth of the performer. This paper focuses on the evaluation of performance practice of İrègún music. İrègún chants and songs is an indigenous music typology of Yagba people in Kogi State, Nigeria. It is a satirical and praise genre, performed by adult men and women with a lead vocalist, and uses imagery to critique social ills and exposes deviant members of the society. Iregun singers satarises boaster who takes unnecessary credit for helps rendered to others. The musician also sings the praise names of philanthropists who helped others and do not take unnecessary credits. In this way, İrègún music, through satire and praise, has played very significant roles in the social life of the Yagba communities.

\section{The Concept of İrègún}

İrègún is a concept among Yorùbá ethnic group which means glorying as a result of help rendered to another person and making such effort known to others. According to Yorùbá dictionary, İrègún means sise ògó lórí isé rere tí enikan se fún enikejì fún àpere kí enikan so wí pé kí kibáse torí tèmi kòle dé ipò tí ó wà ye o. (That is, irègún means taking glory unnecessarily for help rendered to others. For instance a statement like if not for me he cannot get to that position). In the album of Olátúnjí (2011), he refers to God as Oba ton sore lai se 'règún. Likewise in some of the Yorùbá proverbs/adage we have statement like "Aríse ni aríkà, aríkà ni baba ìrégú. Ohun tí a bá se ní òní, òrò ìtàn ni bí ó di òla”- what you have done is what people will recollect about you). It, therefore, means that irègún word is used in different situations, like rallying, insulting, and mocking others. Also, it is used in remembering past events that takes place in the society. One of my informants rightly explains that irègún is used to remember past event that people have done whether good or bad. Irègún songs, therefore, focuses on insult, rallying and mocking originally. It is also used to remember the activities of individuals in the community, who have made the community proud. Socio-cultural studies that examine cultural practices among the Yagba in Kogi state of Nigeria have been extensively carried out by such scholars as Ijagbemi (1976), Iyekolo (2000, 2009), and Metiboba (1998). These studies have resulted in the documentation of Yagba cultural practices such as traditional belief system, funeral rites, politics and kinship. Also many scholars have researched into different musical typology of Yoruba people among them are Barber (1991), Vidal (2012), Adedeji (1998, 2004), Ajibade (2013) Omojola (2006, 2012) 
and Euba (1990) among others. However, in-depth ethnomusicological studies of Yagba musical practices, particularly the performance of İrègún chants and songs are still largely unavailable. Apart from sketchy comments by Iyekolo (2000), within which the pictures of the musical instruments used in Yagbaland including the ones used in İrègún music and performances were shown, no detailed study has been carried out on the performance of İrègún chants and songs.

This paper, therefore, investigates the performance of İrègún chants and songs in Yagbaland. The aim of this paper is to analyse chants and songs performances during the different stages of İrègún performances deployed for burial, and marriage ceremonies. Other objectives are to examine the uniqueness of the orality in Yagbaland. Yàgbàland is in the present-day Kogi State located at the north-central part of Nigeria and situated along longitude 7.30 o to $9.34 \mathrm{o}$ E and 7o to 8 o N. See Map, examples 1, and 2 on Yàgbà, Okun-Yorùbá, and Nigeria where Kogi state is situated. This area is most often referred to as the Middle-Belt region of Nigeria inhabited by other ethnic groups like the Ebira, Tiv, Igbominal, among others (Iyekòló, 2006). The Yàgbà were formally under Kabba Province in northern region with the headquarters in Kaduna. However, following the creation of six states out of the northern region in 1967, it became part of Kwara state with headquarters in Ilorin. Further restructuring of the country in 1991 by the then military Head-of-State, General Ibrahim Gbadamosi Babangida led to the creation of more states including Kogi State with headquarters in Lokoja. Kogi state has three major ethnic groups -Igala2, Ebira3 and the Yorùbá-Okun people. Kogi State comprises of 21 local government areas. Yàgbà ethnic group falls under the Kogi West Senatorial District which incorporates all of Okun land. These include Yàgbà-East, Yàgbà-West, Mopa-Muro Local Government Areas, Owé and Bùnú in Kàbbà/Bùnú Local Government Area; İjùmú and Gbede in İjùmú Local Government Area. Yàgbà has an area of 3,519 $\mathrm{km}^{2}$, and has boundaries with the Nupe and İgbómìnà in the north, the Èkitì and Ondo in the south and south west, Ijùmú and Bùnú in the south-east and east.

Yàgbà is one of the minority groups in Kogi State of Nigeria. There are over seventy-five towns, villages and hamlets. Following the 2006 census, the population of Yàgbà people was estimated to be three hundred and thirty-three thousand, two hundred and ten-333,210 (Nigeria LGAs population, internet, 2009). Yàgbàland has an undulating contour marked by dotted chains of hills interspersed with small rivers. The climate of Yàgbà is tropical, with two seasons: raining and dry seasons. The raining season extends from April to October, while between November and March the weather is dry. During the early part of the dry season, the Harmattan wind from the Sahara sweeps across Yàgbàland, resulting in relative low weather temperature. 
Oral history reveals that the Yàgbà are Yorùbá and descendants of a renowned Princess from Oyo, who, in her later life, was called İyá-àgbà (old woman) from which the word Yàgbà was derived (Iyekòló, 2000, and 2006). She led a group of immigrants from Old Oyo, and settled at Akata-Ere in the present Yàgbà West Local Government Area of Kogi State, over four hundred years ago. Iyekòló reports that some Yàgbà people claim they are from Ile-Ife. The Yàgbà from IléIfè include Yàgbà from Mopa, Ifè-Olúkòtún, Ėùkù and İsánlú communities. He confirms the periodic visits of Yàgbà Ifá priests to Ilé-Ifè for consultations.

Simoyan (1991) reports that some of those who settled in Akata-Ere later left to settle at ilái, now in Mopa-Muro LGA. Another group moved to settle in Awoyo in southeastern part of Yàgbà in the present Yàgbà East L.G.A. Métibóba (2006) explains that the expression Yàgbà-Yorùbá is used to refer to a distinct socio-linguistic unit of the Yorùbá cultural group. The term okun3 is a mode of salutation common but not exclusive to the area. Yàgbà therefore, refers to the people and their language and is applied to the geographical area which they occupy. Johnson (1921) notes that the Yàgbà are north-easterly sub- ethnic groups of the Yorùbá; they are distinguished by their long tribal marks on each cheek meeting at an angle of the mouth. Today, just a few elderly people can be seen with marks, as they are no longer in vogue due to modernization. Formerly, Yàgbà villages consisted of a number of units, independent of one another and recognizing no central authority. Iregun music is one of the major social-cultural musical heritage of Yagba people and it is been passed from generation to generation among the performers. It is also pertinent to know that iregun chants performers vary their performances base on the functions and ceremonies. During wedding it is not a strange things to see performers singing satirical songs before, during and after the wedding ceremonies. They also sing the praise names of individuals before, during and after performances.

For this paper three communities were selected in from the three Local Government Areas in Yagba land; Isanlu in Yagba-East L.G.A, Egbe in Yagba-West L.G.A and Mopa in Mopa-Muro Local Government Area where the practitioners live. The researcher carried out the research using qualitative in sourcing for data. Which include three Focus Group Discussions. This was done with each performers in each LGA. Also personal interviews were conducted with leaders of the performers in each of the LGAs.

\section{Performance in Africa}

Ilesanmi (1998) explains that chants and songs are two of the five major aspects of music, the other aspects being recitation, instrumentation and choreography. In appealing to human emotions, music has preserved the unwritten records of 
the non-literate age in forms of festivals, rituals and many other socio-linguistic interactions. Even at the alphabetic age, many records are kept in poetic musical forms whose origins are undoubtedly oral and musical. Omojola (2006) notes that musical performances of traditional music do derive meaning and relevance from their association with non- musical events and that they often attract wide and open participation. Such performances are often led by a group of professionals who process a systematic knowledge of their music, and whose composition and performances are underlined by culturally defined philosophy, in which various musical elements like rhythm, melody, instrumentation and formal organization are carefully defined and judiciously combined to achieve desired effects. Musical performance in Africa maintains an integral relationship with other aspects of life. A notable feature of this interaction, is the fact that music is often performed in a multi-media context in which dance, elaborate costume, mime, poetry and drama are featured in a total theatre spectacle (Omojola 2006:17). The location of this total theatre spectacle within the context of religious, social and political activities underlines the indigenous perception of music. These musicians who lead the performances and the community who, in addition, provide critical assessment of the performances, take part by dancing, singing and clapping.

Samuel (2009) notes that within traditional music performances in Nigeria, social roles held by the community can be represented, reinforced, commented upon and even reversed. The musical arena does serve as a forum for such open expression and commentary. Samuel (2009), on the performance of dundun musicians points out that dundun drums combines both musical (ensemble leading) role as well as speech surrogate role. Euba (1990) as cited by Samuel (2009), distinguishes three ways by which iyaalu utilizes literary materials in performance. The first is when iyaalu dundun plays solo as an organ of direct speech without musical attributes; the second instance is when it talks in musical context with the secondary instruments performing purely musical role. The third is when the iyaalu imitates the voice- that is, singing a literary text.

Ogli (2010) asserts that chanting assumes a style that is midway between singing and speaking. He notes that in many African royal courts such as that of the Alaafin of Oyo and Atta of Igala, chants exist and are described as court poetry which is, as an institutionalized art, meant to revere a hero by recreating his achievements in verse. Vidal (1971) defines it as poetry or stylized speech sung to music. Bamgbose (1966), Abimbola (1968), Vidal (1971), Babalolá (1976), Olatunji (1980), Adedeji (1992), Adeleke (2008) and Adédùntán (2009) employ the terminology "chanting" to describe the performance of Yoruba oral poetry. They assert that chanting can be described as a musical style rather than a speech style, because chanting 
is also singing though within a limited scope. Vidal (1971) explains that Sun in Yoruba, means, to chant. Thus, one hears sun rárà ( chant rárà), sun İjálá ( chant ijálá), sun ìyèrè ( chant ìyèrè) and sun iwi (chant iwi). Others are ekúnìyàwó (bride’s lament) ege (an egba chant), Alamo and so forth. Chants can be identified musically by their intonation, narrow melodic range, melodic contours and tonal register.

Vidal (1971) asserts that iwi, iyèrè-Ifá, İjálá and rárà are the four main modes of chants. Iregun performance in Yagba land is mostly led and perform by adults men and women however it is purely non religious music. The iyèrè-Ifá mode has, characteristically, a trembling voice quality, clear and pure tones, and highly structured sequences. It employs a responsorial style of chanting in which the chorus responds with the word hen at the end of every chanted line of the poetry by the leader, who is the soloist. The chanted lines of poetry (about five or six) form a verse, each of which is followed by a refrain chanted by both the soloist and the chorus before another verse is started. The verses are taken from the Ifá liturgy. Iregun uses word kiki/iki whch means to praise in chanting

Adélékè (2008), Adédùntán (2009) and Vidal (1971) explain that the ijálá mode is chanted on a variety of pitches, often nasal and ringing. Babalolá (1976) states that ijálá is a genre of spoken art practised mainly by the Oyo Yoruba people of Western Nigeria. Babalolá (1976) further notes that the origin of ijálá is traced to ògún the Yoruba god of iron, who embarked on chanting, in accordance with a divination that said he would establish his reputation as an entertainer. İjálá like other chants it employs a style, which is midway between singing and speaking. Chants mode of rendition may be characterized as monophonic, which is the use of a voice at a time, as in a solo. Babalola further explains that İjálá is a form of poetry because it is an elevated expression of thought feeling in metrical form. It is solo chanting characterized by a song-like effect and approximating melodious singing. To these choruses are provided at appropriate intervals during the course of chanting, usually with accompanying drums or claps. This mode is easily identified by its nasal and intense tone quality, its wide tonal range, and its melodic contours.

The rárà mode according to Vidal (1971) and Adélékè (2009) is characterized by a long drawn-out wailing tone quality. It uses a nasal vocal quality, with the area around the base of the neck for resonance. Usually a solo form of chanting, in some areas it is sometimes terraced--more than one person singing in parallel seconds above or below the principal part. The intonation varies according to area to which the performer belongs, but its wailing and nasal characteristics are still retained.

Barber (1990) notes that oriki can be described as attributions or appellations: epi- 
thets, elaborated or concise, which are addressed to a subject and which are equivalent to, or alternatives to, names. All entities in existence are said to have their own oriki. Oriki are felt to capture and evoke the essential characteristics of the subject: to have the most profound and intimate access to its inner nature. In utterance, therefore, they evoke the subject's power, arouse it to action, and enhance its aura. They are always in the vocative case, and in utterance the performer always establishes an intense, one-to-one bond with the addressee as long as the utterance lasts. To her Oriki are a labile and disjunctive textual form. Epithets are accumulated over time; they are composed by different people, on different occasions, and with reference to different experiences. Any subject's corpus of oriki is, therefore, composed of a number of autonomous items. Furthermore, oriki are often obscure, their meaning carried in a separate, parallel explanatory tradition transmitted outside them.

Each oriki gestures away from its location within the performed text to a hinterland of meaning outside the text Barber (1990). Barber further notes that not only this, but each oriki may lead to its own hinterland by a different route. Some are literal, some ironical, some are specific historical references and some are generalized comments referring to a timeless or ideal state of affairs. An oriki chant is a shifting, fluctuating combination of fragments, which are linked only tenuously and variably in performance, and which may take on different meanings when differently combined. Oriki are felt not only to encapsulate the essence of the subject, but also to augment its presence in the social and natural world. Towns, lineages, individual people, orisa, egúngún and even animals are enhanced in relation to---sometimes almost at the expense of--other like entities through the performance of their oriki. Iregun oral performance uses oriki. The oriki focuses on the personalities of individuals been praise, his makeup, physical appearance, family history and genealogy in Yagbaland.

\section{İrègún Chants and Songs Performance Practice}

There are three different stages in the performance of ìrègún chants and songs. Maku (an informant) explains that o no meta ki are ìrègún pin ghi; akoko, imura are, are sise loju agbo ati ipari are. The informant in other words notes that there are three sections in ìrègún performance. These include pre-performance, actual performance and post-performance activities. These three sections are explained below.

\section{Pre-Performance Activities among iregun performers}

According to Iya Egbe İrègún, 4 pre-performance of ìrègún music starts with the invitation that is, when the group has been giving an invitation, whether for burial, wedding, launching, house warming, child dedication or chieftaincy title. A 
meeting is then called among the leaders most especially the Iya Egbe and the Baba Egbe Iregun the invitation and which considers the personality, cost, and terms of agreement and to be sure the group does not have another performance on the same date. When all the factors are well considered the favourable message will be sent to the person inviting the group that the group will come on certain conditions of payment, which ranges between 10 thousand to 50 thousand naira depending on the location, time and distance. Ògúnleye, an ìrègún singer, explains that on the day of performance the group would have been ready at least an hour before the performance, if the place is within the town so that they can have time for spiritual preparations and create awareness. Most of the time the group sings from the house of Iya Egbe İrègún to the venue of the ceremony, if the ceremony is within the town, and if it is outside they urge a driver to drop off the group about one hundred meters before the venue so that the group can create awareness. İrègún singers in a procession and creating awareness as they mobilise for a performance at a burial and traditional marriage ceremonies.

\section{Actual Performance Activities:}

İrègún songsand chantsareperformed principallyduringcertainactivitiesandceremonial events involving members of Yagba people whether at home or in the Diaspora. At performances, performerssingİrègúnlinesaspartoftheirtotalinvolvementin themusic. Some ìrègún performers explain that in the process of singing, when they are" moved", they are able to tap into a vast repertory of songs/chants lines which is not always accessible to them outside of the context of the performance. As one of the ìrèun performers explains, "when I am singing, the words come out without my trying to say anything, when I am thinking deeply about the history of Yagba people and what we have passed through". İrègún songs and chants are frequently based on texts on a common stock of traditional lines and themes. The performers alter them in ways which reflect their own personalities and which suit the particular situation about which they wish to comment. İrègún oral performance is chant-based with interjection of song, each dealing with the total life experience of the people, their proverbs, social and political commentaries, encouragements to participants of İrègún music, praise to the present and past members of the family participating; the referencing of common troubles with humour to lighten their burden, and so on. Sometimes a singer slowly weaves his story through this mosaic of different themes. An idea is developed for a while and then droped until later in the song. Sometimes, different ideas are developed at the same time. The İrègún lines are performed as long as the artist remains in the mood and receives new ideas and images from his/her music sensibility. During a performance of İrègún song, a rapport is established between the singers 
and members of the audience as the singers express their feelings, bringing the audience into the challenge of interpreting their song-texts. Since subtlety is an important element in the art of İrègún, performers strive at times to express themselves indirectly and members of the audience must guess at the meaning of their words. It is not uncommon for individuals listening to a performance of İrègún music to derive differing meanings from the singers. The explanation for this can be found in examining a number of different factors related to the performance of İrègún. They range from the techniques utilized by singers in a deliberate attempt to obscure their meaning to the different contexts in which the performance of İrègún is heard. İrègún singers frequently express their feelings about personal, social or political issues, through allusions rather than direct statements. An informant reports that this is accomplished by using such forms as traditional Yagba language proverbs (oghe), parables (itan abi alo), and secret language or obscure allusions.

According to an informant, İrègún songs and chants are led by a chanter or/ and song leader. He /she starts by greeting the people that are seated at the ceremony from the highest person, who could be a king or a chief; and he/she could just chant to praise and thank everybody for coming for the occasion. İrègún ensemble, led by a chanter includes the drummers and dancers. Sometimes the chanter is also the lead dancer. In all the performances of ìrègún, the performance procedure is similar and often follows a sequence. The sequence, according to Iyabode, an ìrègún singer, is that chant will come first, followed by the song; the musical instruments; then dance will come last. In any of the performances the first chant and song is generally to greet members of the audience. 


\section{Chant 1}

E okun o loke lodo Igho mum' moran de be ekun pepe, Oniyan biwo gho sian am' sebo buru, Mo wa ghin loke lodo gbogbo gha pata

Mo wàn li kwara li gbogbo Nigeria, lomode lagba lobinrin Lokunrin, Mo wa ghin loke lodo gbogbo ghin pata, Eku ri rin eku rabo e o kun o, Ayeye olurobe dalugbo, omo alapo isojo ghere ghere, Omo letija, omo li sele e okun o, Mo wa'n, Eku ri rin eku raboE ku farada, Jesu ase gho sian ghun gbogbo gha pata, A ke moin lule tele loju araiye, Aseye k'alakan ise poin, Ori aje ghun sian a senilegbe, ti gha je gbo seti, Tigha dunmoni, adun megbe li gbo gbo aye,

Toba oba noin akalesoke tan gha dope, $M g$ bo ikuborije, kibarare senle, Oba kabiyesi, obatorise oba teran enu saka Ati oran Tile mokan je, Amoko aje mudamuda oka pasa, Oro ken le oroke lalade, Oba saki, oba 'sanlu kuratijo, Mo rio l'alafia e ro kun o, Irohin etafojuba esono gbon tan,Oba arinurode o, modepe lowo jesu oba olola, I gho gbem re, agbem bo,agbem sokesodo, onimodele,Afara bale ejem ranti,

Mgbo kabiyesi isawele ...aga/dara

Mo wa ghin loke lodo e okun o,

Akande olinuoro o kun o,

Alafia kose, eja dupe lowo jesu oba olola, Baba furaide egbegbere ijoko ijotile,Iranni sitoko, pasu baba mgbo omo olori ode, Ode gho gba samsam, ode gho pa tutu, pa bigbe,

Omom olose ya kankanran, egbeni sesese, Song 1

solo Igha mori segbe regun ape ade o

Chorus Igha mori segbe regun ape ade o Solo Igha mori samuludun ape ade o Chorus Igha mori segbe regun ape ade o
I greet you all my people, I say I greet you when one is looking at what is good people will is wicked, I greet you all

My people from kwara, Kogi, all over Nigeria

Women, men young and old

I greet you all

Ayeye you re the true son of your father

son of the real father you are

I'm greeting you all, you have really endured to be,

here, Jesus will bless all of us as we are here we will not fall in the present of enemy may destiny prospers us

sothat life will be pleasant for us

so that friends can rejoice with us

even kings will see the goodness and they too will be happy, I greet you my king, Ikuborije the Agbana of Isanlu land the great leader, whose father is a great leader

I hail you, my king,

I great you my king long time, hope you are living in good heath

I thank Jesus the king that knows all things He that protected me when I was going will bring me back safely.

I am greeting all of you once again

I greet you

Akande the son of the gods I greet you, Hopeyou are fine

Friday's father the blessed one how are you The son of the chief hunter how is home, I can remember that your father kill big animals, in the rain and also during dry season is a specialist in hunting

We are İrègún singers and we have come We are İrègún singers and we have come We are the merry makers and we have come

We are İrègún singers and we have come 


\section{E OKUN O}
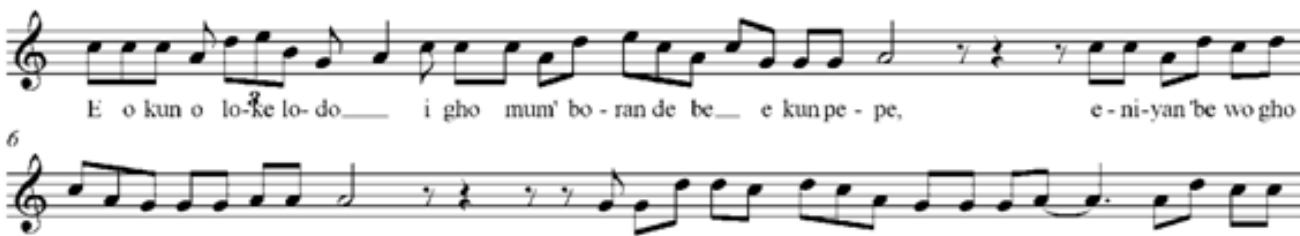

si ghan am' se bo bu - ru,

mo wa ghin lo-ke

lo-do gbo gbo ghin pa ta,

11

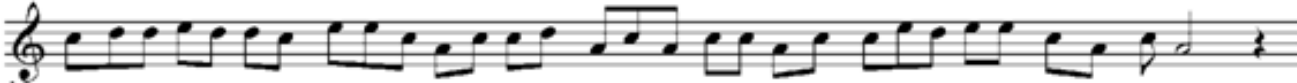

16 Kwa-ra li Ni-ge-ri-a lo-mo-de la-gba lo bi - rin lo kun-rin mo waghin lo-ke lo-dogbo-gboghin pa-ta

(2)

22 e-kuririn e-ku-ra-bo e o-kuno A-ye-ve o-lu ro be da lu gbo o-mo a - la-po i-so jo ghe-re ghe-re o-mo le-ti-ja

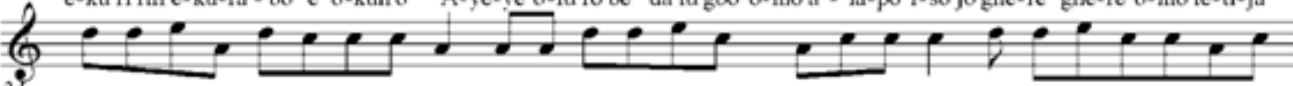

29 o-mo li se le e o-kun o. mowa'n e ku ri rin e ku ra bo, e ku ta ra da Je-su

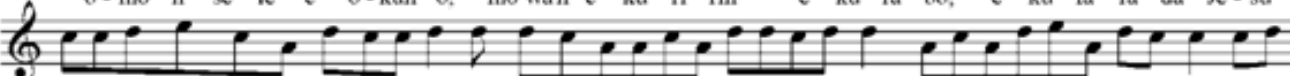

a-seghosithan ghun gbo gboghapa ta, a ke moin lu le te-le lo ju a-rai-ye, a se ye k'a-la-kan i se poin, o ri
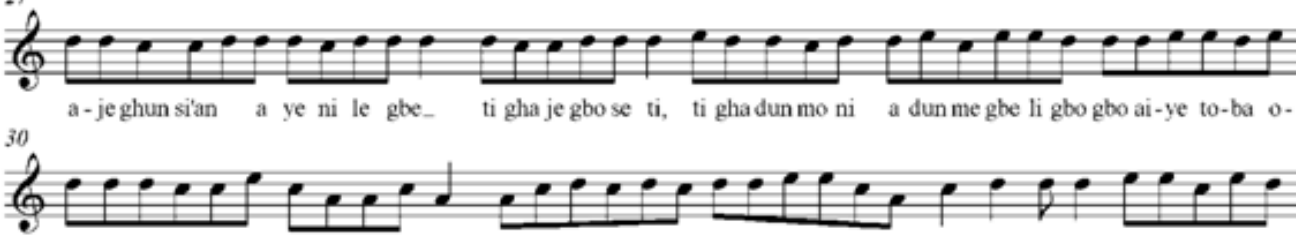

ba noin a-ka-le soke tan gha d'o-pe-, mgbo I-ku-bo-ri-je ki ba ra re sen-le - o-ba ka-bi-ye-si o-

3

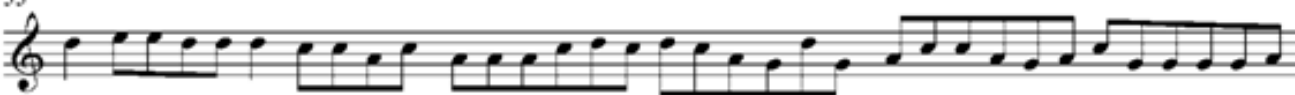

ba to ri se o-ha te ran e-nu sa-ka, a-ti o-ra ti le mokan je a gha do a moko a-je mu da mu da 6 is

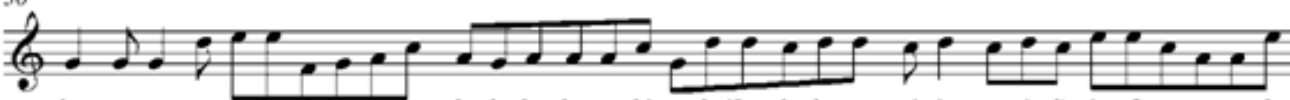

ka pa-sa, o ro kenle o to ke la la deo-ba sa-ki o-ba'San-lu ku ra ti jo, mo rio ta la fi a e ro kur 39

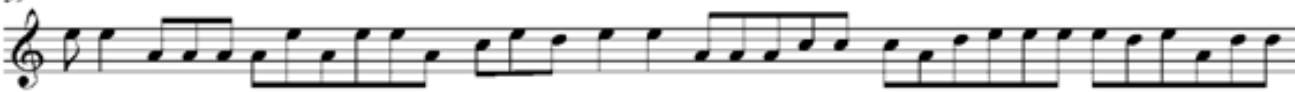

- o, i ro hin e ta fo ju ba e so noghontan, o-ba a-ri nu ro de mo de pe lo-wo Je-su o-ba $o$ 42

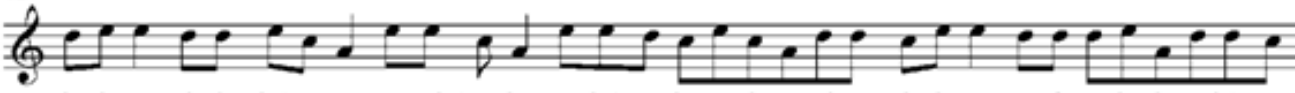

lo la, - i ghogbe'm re, a ghe'm. bo, a ghe'm so ke so do o ni mo de le, - e fa ra ba le e jém ran 45

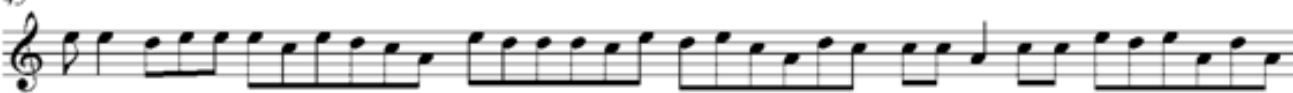

ti, - 'm gboka-bi-ye-si i sa we ke a ga ra mowaghin lo ke lo do e o kun o, A-kan-de o li nu o-ro 


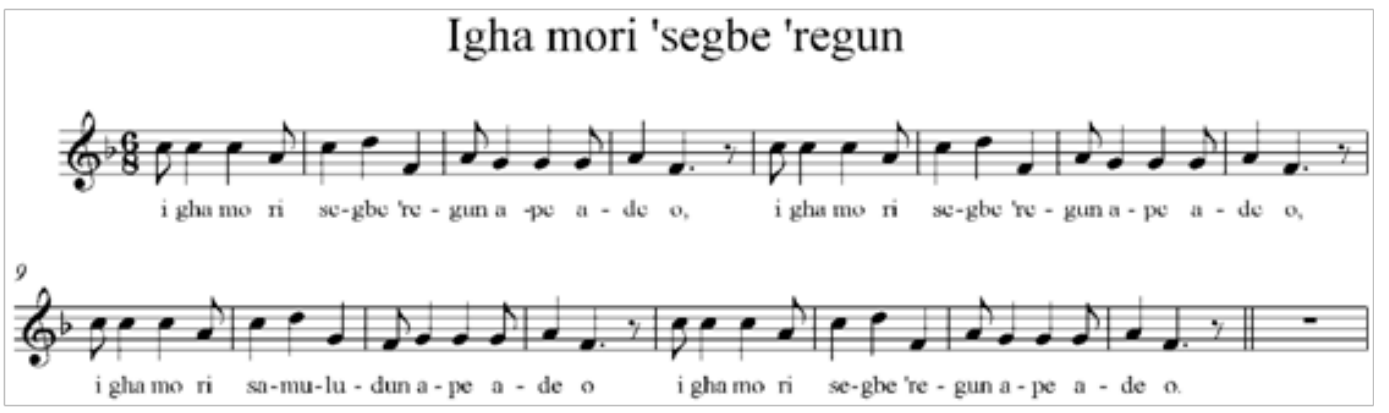

The chant above is a general greeting to people, male and female, and Agbana of Isanlu Oba Ikuborije. After the chanting, the ìrègún chanter, who is also the song leader, introduces the song which is chorused by the back-up singers, dancers and drummers, as the case may be. The chant above expresses respect for elders in the community and also at an occasion in the indigenous Yagba society. E okun is a plural way of greeting two persons or more; it also connotes reference for elderly persons in Yagba communities. Also the expression e okun pe, pe, is generally used for elderly man that is not less than sixty years old. pe is similar to saying "I am greeting you, grandfather" or to someone who is not less in age than the speaker's age. The words l'omode, 'lagba , 'lokurin, 'lobirin are ways of specifying different age groups and sex/ Individuals were recognised in the song like Friday's Father, Akande and their praise names chanted. The homage is usually followed by the introduction of the group members and their leader through special songs/chants as for example in a wedding ceremony.

\section{Death and After life in Iregun Chant and Song}

This category consists of songs dealing with the themes of death and the after-life. These songs enable individuals to express sorrow over the difficulties in their lives, as well as to express anxiety about, and apprehension over, such universal problems as the confrontation of death. The second chant and song is a song eulogizing an ìrègún matron who is being buried.

\begin{tabular}{|l|l|}
\hline $\begin{array}{l}\text { Chant 2 } \\
\text { iye ha ho'ku ise ki hin mi jeje, } \\
\text { eni bukata ihin mi jeje } \\
\text { iye ilodo jesu tehin mi jeje }\end{array}$ & $\begin{array}{l}\text { Our mother that is been buried today } \\
\text { she is just resting fully, she does not worry } \\
\text { of Jesus with everlasting rest over issues of life } \\
\text { again, she is at the feet } \\
\text { Our mother is at the feet of Jesus resting } \\
\text { solo: iyeye ilodo jesu tehin mi jeje } \\
\begin{array}{l}\text { Ohorus: iyeye ilodo jesu tehin mi jeje } \\
\text { solo: iyeye ilodo jesu tehin mi jeje } \\
\text { chorus: iyeye ilodo jesu tehin mi jeje }\end{array}\end{array}$ \\
\hline
\end{tabular}




\section{IYE GHA GHO KU MO}

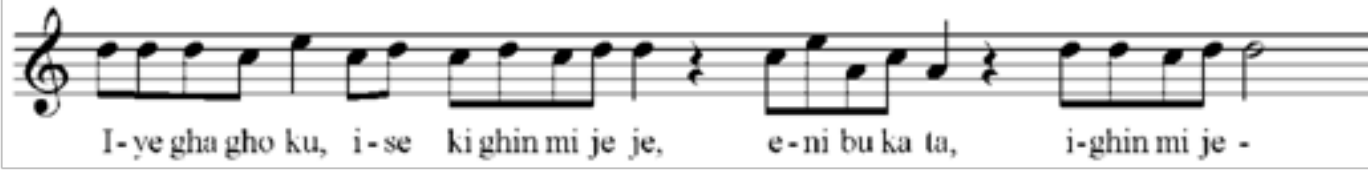

IYEYE ILODO JESU

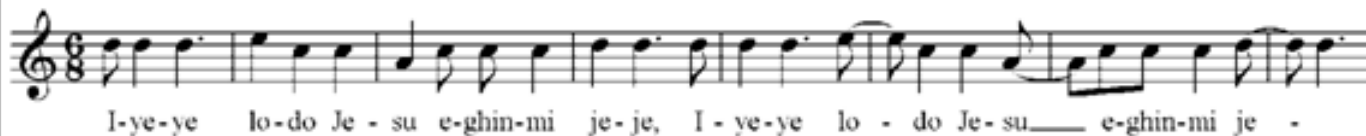

The chant and song above inform us about the death of one ìrègún lover and fan. The chanter remarks in the chant and song that the mother who is dead is peacefully resting; that in the present state, the deceased does not have any anxiety. This is an example of issues that tell us about life in the beyond and also deals with metaphysical reality.

\section{The Singers Needs}

This category consists of songs about the needs of the chanters/ singers. At times, singers refer directly to their own troubles as illustrated in such chant and song as Ibanke aisan me sem'. At other times, the images within İrègún portraying troubles are cryptic, having meaning only in the context in which they are sung, or having meaning only to the singer. Feelings about needs may also be expressed through humor. See an example in the chant and song three.

\begin{tabular}{|c|c|}
\hline $\begin{array}{l}\text { Chant } 3 \\
\text { E pe banke kom' oniganran ijoni } \\
\text { Banke oni ganran ganran ijo ni } \\
\text { Aisan me sem' lowo,O ba mo se banke li gbogbo, Le } \\
\text { yagba lero tan, Ibanke nikan soso koro tan, } \\
\text { Alalum' se we gbo banke we mo gbo hin dunm' } \\
\text { Ebi hin pam' linu eta run gbe, me, } \\
\text { Song } 3 \\
\text { Solo: Gha mu kere somi komarun gbe } \\
\text { chorus: Gha mu kere somi kom’arungbe } \\
\text { Solo: Gha mu kere somi kom'arungbe } \\
\text { chorus: Gha mu kere somi komarungbe } \\
\text { Solo: Gha mu kere somi komarungbe } \\
\text { chorus: Gha mu kere somi kom’arungbe }\end{array}$ & $\begin{array}{l}\text { Help me call Banke, who resemble } \\
\text { the mother so perfectly } \\
\text { Banke, I want you to know that I am } \\
\text { ill, } \\
\text { and it is only you that can heal me } \\
\text { my drummer, hope you are listening to } \\
\text { Banke, do you know the sickness? } \\
\text { The hunger that facing is not as much as the thirst } \\
\text { come and use cup to fetch water to quench my } \\
\text { thirst } \\
\text { come and use cup to fetch water to quench my } \\
\text { thirst } \\
\text { come and use cup to fetch water to quench my } \\
\text { thirst }\end{array}$ \\
\hline
\end{tabular}




\section{IBANKE}
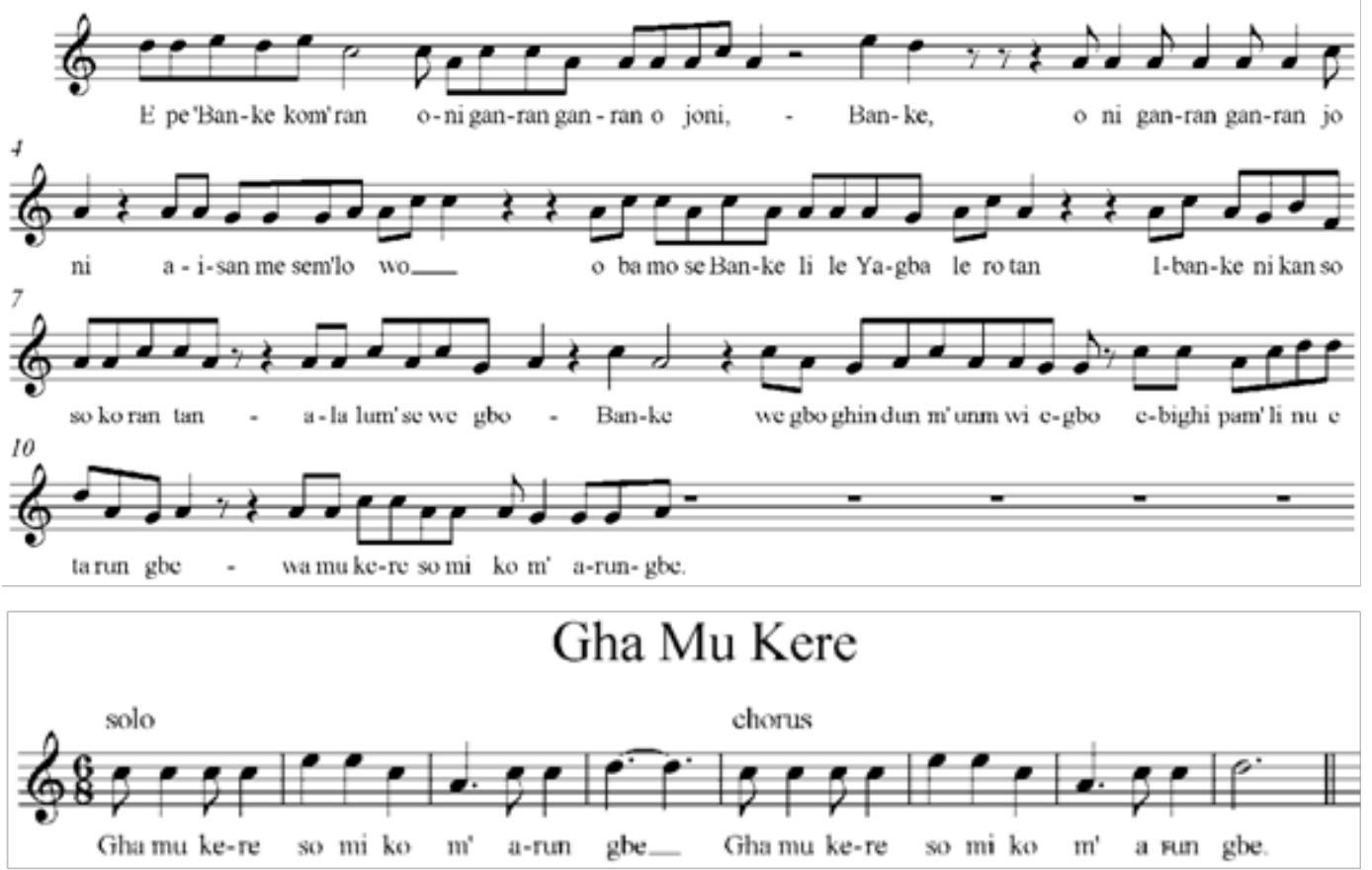

The singer here is calling a daughter of the dead woman, called Banke and eulogizing her that she resembles her mother. The chanter says that he is presently sick and that it is only Banke that can bring the healing. He says that though he is hungry, the thirst is not up to the pain he is experiencing at the moment; that she should use kere-cup to bring water for him to quench the thirst. However, in actual sense, he is telling Banke to bring wine for him to drink.

\section{Social and Political Commentary}

This category consists of chants and songs offering social and political commentaries. İrègún chants and song of this type are similar to those reported in other cultures, which, through admonition and ridicule, seek to modify the behaviour of those individuals who have strayed too far from the respected norms of the society. Chant and song four are examples. 
Chant 4

we ri ho lijo gbede loin,bitonran ijoba noin I gho moye ijoba nse, era gbe pona kobe Ara gbe kob’o mirin libo janjan

Igho ye o gba megadi hi,ijoba egba megadi so igho bamoye ogba megadi hi, ke gba megadi so, oba ko ofisi hile ako pepa hofisi ara so oba ran mirin he wuni ara gba megadi hibe hun ra so, oniha noin emo ho ye aso, arun koje so

Song4

solo : ononi un toju arun re arun jeso chorus : ononi un toju arun re arun jeso

solo : ononi un toju arun re arun jeso chorus : ononi un toju arun re arun jeso
Don't you see my dancers, like our government what they suppose to do they will not do, the things that they should not do that is what they do. For instance if they suppose to construct a road, at a place they will not construct it, if they need, to put a security at a place they will not do it, they can put a paper in one office and, take heavy security on ordinary paper instead of securing lives, my people what we should secure is our mouth, secure your mouth its worth securing, keep your mouth my people it's worth keeping keep your mouth my people it's worth keeping

\section{Ijoba Gha}

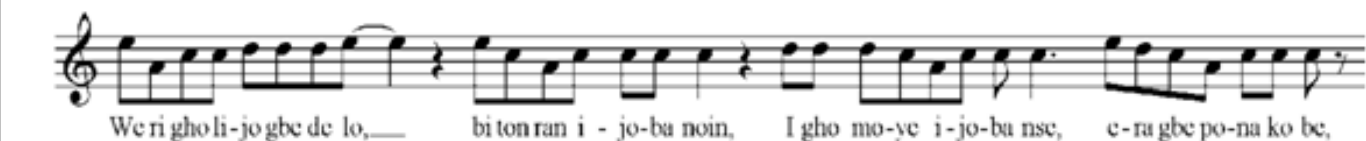

6

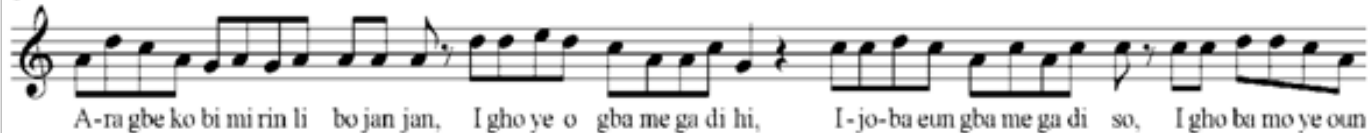
II

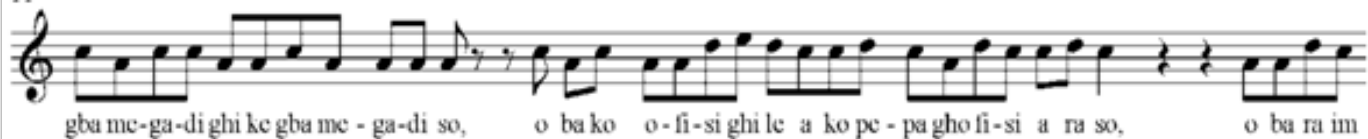
16

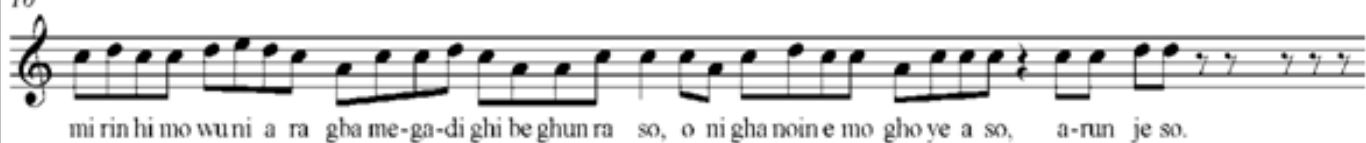

\footnotetext{
mi rinhimo wuni a ra gha me-ga-dighi beghun ra $\$$, o nighanoine mo gho ve a so, a-run je so.
}

\section{Arun Jeso}

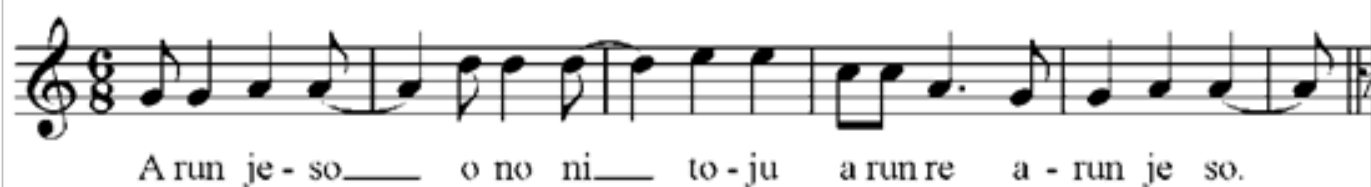


The song starts with a chant and the chanter is explaining to the audience that the corrupt leaders in government, (both indigenous and democratically elected), find ways of impoverishing the community they govern through unconstitutional awards of contracts such as roads. Line two of the chant says for instance, I gho moye ijoba nse, era gbe pona kobe. That is where they are supposed to construct a good road, they will not construct it, therefore, showing a lack of focus, sensitivity to the need of the populace, and corruption because either divert the money to their own private pockets or construct bad roads that will need repair few months later. The song also talks about the fact that good governance entails good security of people, goods and the community in general. However, the government that is not governing well will rather employ the "megadi" types of security officers. And, instead of securing human lives, the government keeps them securing and protecting empty ofisi-office. This depicts the extent of bad governance. The singer, however, cautions, the audience that, though the government is not really responsible until they prove themselves innocent of the allegation levelled against them by the ìrègún singers on good governance, they have a duty to make security a priority and that starts with arun jeso; that is, secure or protect your mouth from tale bearing, lying and keeping quiet where necessary, so that their life and future can be protected.

\section{Historical References}

As in the poetry of historical songs found in other African cultures, İrègún chants and songs provide brief allusions to significant incident rather than a detailed narration of events (Nketia, 1974:197). Chants and songs in this category include references to the personal past of individuals, to incidents which have broader significance for members of the lineage of the singer, and to important events concerning Yagba people as a whole. An example is in Chant and Song 5 below:

\section{Chant 5 \\ momo pansaga se teletele latijo \\ alu nla se wegbo \\ momo pansaga se teletele latijo \\ we mo ghe ti jem se pansaga m'wi egbo mo rom se bi ato hi ha mo soun ko}

\section{Song 5}

solo: imògún ese batohi pamo were chorus: imògún ese batohi pamo were solo: imògún ese batohi pamo were solo: imògún ese batohi pamo kia chorus: imògún ese batohi pamo were
I like chasing women in my early life my drummer are you hearing me I like chasing women in my early life do you know why I stop that habit, I will tell you today, I may be thinking that I got STD, from the lady and may not and it may be charm

charm kill faster than STD that is why I stop charm kill faster than STD that is why I stop charm kill faster than STD that is why I stop charm kill faster than STD that is why I stop 


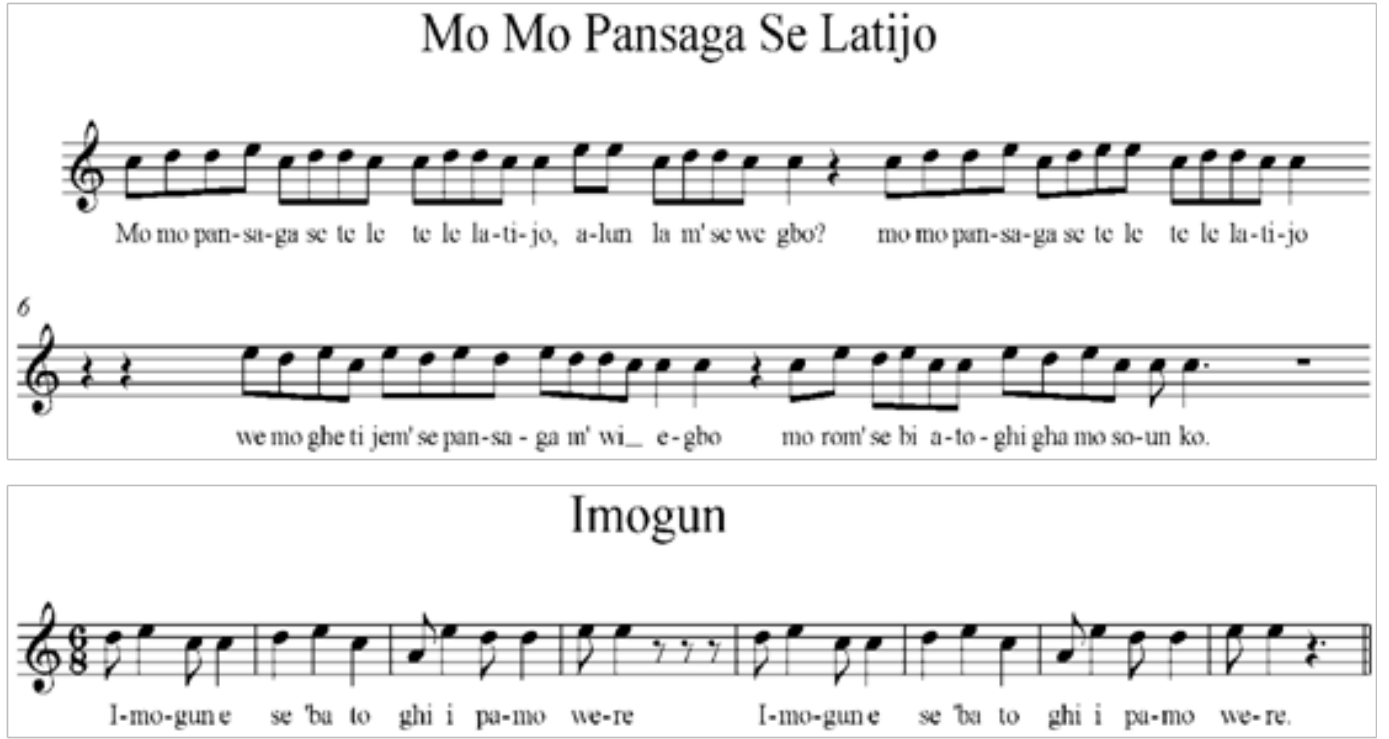

The chanter tells of his personal story using his own story as a philanderer and this is used to pass a message to those that still have the habit of womanizing that HIV is in town. HIV/AIDS is one of the life-threatening diseases that people must be aware of .

\section{Commentary on Events Taking Place at the Time of the Performance}

This category of chants and songs includes statements that offer commentary on the events which are taking place right at the time of the performance, including the participationofthosepeopleinvolvedinthemusicalevent.Seeanexamplein Chant6andSong6.

\section{Chant 6}

alu nla emo bam se kilo h'Egere

Egere o ,egere egere,

Oni noin emo bam se kilo h'Egere

Song 6

solo: oba mu’jo gbo’ya oloya me'un gbin chorus: oba mujo gboyaoloya m'eun gbin solo: oba mu’jo gbo'ya oloya me'un gbin chorus: oba mujo gboyaoloya meun gbin
My chief drummer help me warn Egere,

Egere, Egere Egere

everybody help me warn Egere

if in the process of dancing you snatch another man's wife, I will not talk if in the process of danciang you snatch another man's wife, I will not talk 


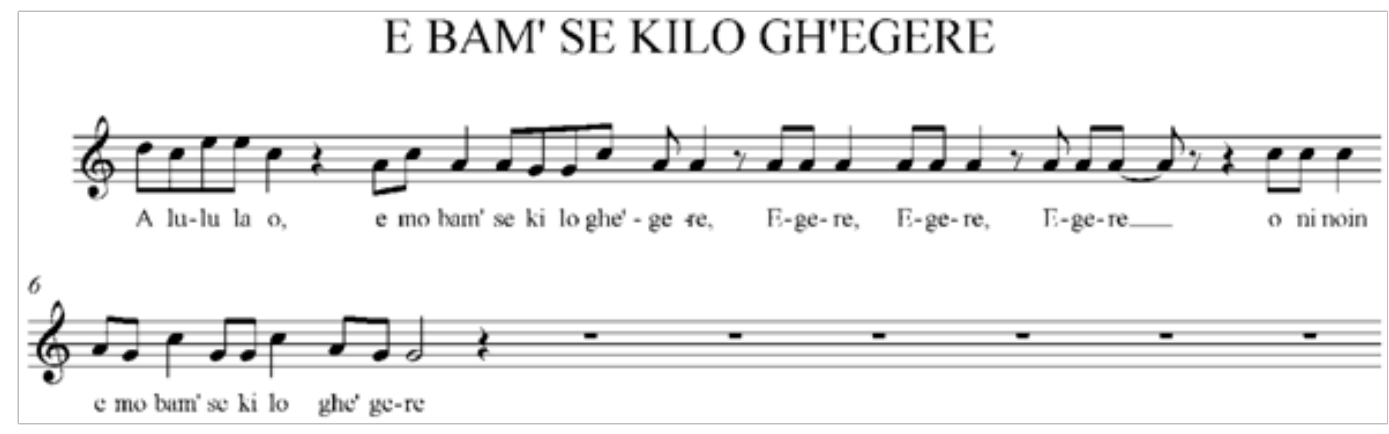

\section{O ba Mu 'Jo Gh'oya}

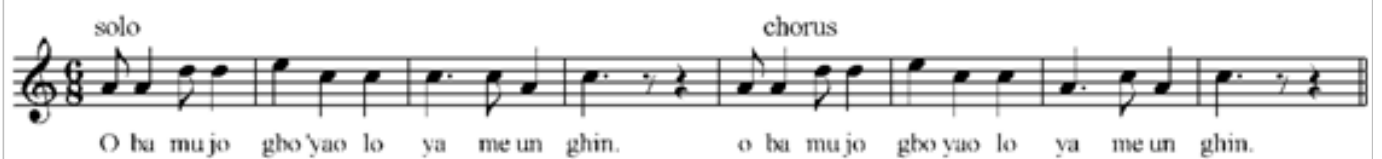

The chant starts by calling the chief dancer who is a male, named Egere. Egere is actually dancing with another female dancer at the moment. The chanter using satire asks that members of the ìrègún group should please warn Egere; that he should not through dance take another man's wife, since the woman is already married. The chanter concludes that if Egere succeeds in taken another man's wife after the warning, he will not defend him when he is facing the trials of taking another man's wife. The song teaches us to live in peace and not take what does not belong to us. Do not still people's money, wife, and landed property.

\section{Post Performance Practices}

Post-performance activities include the assessment by the performers themselves of their own performance; eating their food, sharing of the money that they got at the performance which is done according to leadership role and position. The leader who is the song leader will have greater share than the rest and then some part of the money will be kept with Iyá Egbé as the treasurer for future use. After the sharing, they plan and make preparation for future performance. 


\section{Conclusion}

The paper has examined the performance of İrègún chants and songs as employed during wedding and burial ceremonies in Yagbaland, which are sectionalized into three parts; the pre-performance, actual performance and post performance procedures. İrègún performance is one of the sources of entertainment for Yagba people in Nigeria. As discussed in this paper it is an oral performance though with musical accompaniment. İrègún chants and songs performances present a wealth of knowledge and stimulate learning experiences among its audience. The performances explicates the needs of the performer and the audience, give some historical issues and eulogises when needed.

\section{End Notes:}

1. Nupe Imperialism (Ògún Ibon abi tapa) means Nupe war: ibon or tapa are the names given to Nupe people who enslaved Yagba people in the 19th century before the British colonial masters arrived in Yagbaland. 2. Ibadan imperialism (òún Ibadan) Ibadan people are Yoruba people of southwestern state. They also imperialized Yagba land during the 19th century. 3. Àgbànà of Isanlu is the title of the paramount ruler of Isanlu in Yagba land, 4, Iya Egbe İègún- this is the administrative position of irègún musical group. she serves as the PRO, and Accountant to the group.

\section{People interviewed}

Chief Makanjuola $\mathrm{O}$ - chief drummer ìrègún musical group Mopa-Muro LGA. Yagba Land.

Chief Mrs Funke Aduta - chief singer/ chanter and Dancer İrègún Musical group in Egbe, Yagba-West LGA.

Chief Wemimo Ògúnniyi - a singer and chanter ìrègún group in Yagba-West LGA. Mr. Maku Sunday- Chief singer İrègún Musical Group Mopa-Muro LGA.

Mrs. Olu- Tete - she is a dancer and a singer of İrègún Musical group from Isanlu, Yagba-East LGA.

Chief Mrs. Grace - Iya-Egbe İrègún and a chief dancer from Mopa-Muro LGA.

Chief Kayode O. the Otun Oba of Ejiba land

Iletògún (2009) cultural festivals in Yagba-West

Local Government Area of Kogi state. An unpublished material 


\section{References}

Abimbola, W. 1976. Ifa: An Exposition of Ifa Literary Corpus. Ibadan: Oxford University Press. Adedeji, S.O. 1992 Ifa Music in Ijo Òrúnmìà. Dissertation. Institute of African Studies, University of Ibadan. xxxvi+225.

Adeduntan, K.A. 2009. Text and Contexts of Yoruba Hunters Narrative Performance. Thesis. Institute of African Studies, University of Ibadan. xvi+260.

Adeleke, A. A. 2008. İyèrè Ifa in Yoruba Culture. An in-house seminar paper. Presented to Institute of African Studies, University of Ibadan.

Adeleke 2009 An Ethnomusicological Study of Structure and Form of İyèrè Ifa Thesis. Institute of African Studies, University of Ibadan. xvi+290.

Agu, D.C.C.1999. Form and Analysis of African Music. Enugu: New Generation Books.

Akin, E. 1990. Yoruba Drumming. Bayreuty: Bayreuth African Studies.

Akpabot, S.E. 1998. Form, Function and Style in African Music. Ibadan: Macmillan Nig. Pub. Ltd. Akpabot, S.E. 1981. Musicological Approach to Efik/Ibibio Oral Poetry. Nigeria Magazine.

PP86-95.

Babalola, A. 1966. The Content and Form of Yoruba Ijala. Oxford : Clarendon Press.

Babalola, A. 1967. Ijala: The Traditional Poetry of Yoruba Hunters, in Beier U. Ed Introduction to African literature. Ed. London: Longman.

Bamgbose, A. M. 1966. The Form of Yoruba Proverbs. Odu iv. 74-86.

Barber, K. 1984. "Oríkì, Women and the Proliferation and Merging of “òrìsà". Africa. Journal of the International African Institute, Vol. 60, No. 3 (1990), pp. 313- 337 Edinburgh University Press. Stable URL: http://www.jstor.org/stable/1160110 Accessed: 30/11/2009 08:15.

Barber, K. (1991). I Could Speak Until Tomorrow: Oríkì, Women, and the Past in a Yorùbá Town. Edinburgh. Edinburgh University Press.

Barber, K. 2003. Text and Performance in Africa. Bulletin of the School of Oriental and African Studies, University of London, Vol. 66, No. 3, pp. 324-333: Cambridge University Press URL: http:// www.jstor.org/stable/4146096 Accessed: 30/11/2009 08:09.

Blacking, J. 1967. Venda Children's Songs: A study in Ethnomusicological Analysis. Johannesburg: Witwatersrand University Press.

1971. Deep and Surface structure in Venda Music. Wachsmann, P.K. Ed. Essays on Music and History in Africa. London: North Western University Press Pp 91-94.

Idolor,E.G. 2001.Okpe Disco: A New-Traditional Nigerian Popular Music Genre. Thesis. Institute of African Studies, University of Ibadan.P 568

Ijagbemi,A. 1976. The Miracle of Yagbaland: Christian Missionary Activity in the Northeast Yorubaland. Orita.

1984. Protest and Reform: The Mokobon Movement and the Administrative Re-organisations in Yagbaland. Nigeria magazine no. 149.

Iyekolo, E. B. 2006. A History of the Okun-Yoruba People. Nelson Publishers Limited Lagos.

-- 2000. A History of the Yagba People. Nelson Publishers Limited Lagos.

Nzewi, M 1991. Musical Practice and Creativity: An African Perspective. Iwalewa Haus: University of Bayreuth.

Ogli, G. E. 2010. Idoma Funeral Rite an Ethnomusicological study. Unpublished Ph.D Thesis., University of İbàdàn. xvii+263.

Okunade, A. 2010. Comparative Studies of Egba Palace Music. Unpublished Ph.D Thesis. University of İbàdàn. xvi+198. 
Olatunji, O. O. 1980. Iyere Ifa: Yoruba Oracle Chant. Readings in Yoruba Chants.Ed. Olatunji Department of Linguistics and Nigerian Languages, University of Ibadan PP 151-187 1984. Features of Yoruba Oral Poetry. Ibadan. University Press.

Omojola, B. 2006. Popular Music in Western Nigeria: Theme, Style and Patronage System. IFRA, Gold Press Ltd. Ibadan.

.............2012. Yoruba Music in the Twentieth Century: Identity, Agency and Performance Practice.

Samuel, K. M. 2009. Female Involvement in Dundun Drumming Among the Yoruba of Southwestern Nigeria. Thesis. Institute of African Studies, University of Ibadan. xvi+276

Titus, S. O. (2013) Structure and Function of Iregun Music in Yagbaland, Kogi State, Nigeria. Unpublished $\mathrm{PhD}$ Thesis. University of İbàdàn. xvi+243

Vidal, A. O. 2004. The Poetic And Musical Forms of Yoruba Songs. Nigerian Music Review No.5. Music Department, OAU, Ile-Ife pp 1-17

- 1971 Oriki, Praise Chants of the Yoruba. Dissertation. University of California Los Angeles.xiii +185 